\title{
Hygienisointikäsittelyjen vaikutus pilkottujen tuorekasvisten laatuun
}

\author{
Hanna-Riitta Kymäläinen ${ }^{1)}$ ja Risto Kuisma ${ }^{1)}$ \\ Helsingin yliopisto, maataloustieteiden laitos, PL 28 (Koetilantie 5), 00014 Helsingin yliopisto. hanna- \\ riitta.kymalainen@helsinki.fi,risto.kuisma@helsinki.fi
}

\section{TIIVISTELMÄ}

Kiinnostus pilkottuja tuorekasviksia kohtaan on kasvanut viime vuosina. Pilkkomisessa tapahtuva kasviksen solurakenteen rikkoutuminen edistää mikrobien lisääntymistä ja tuotteiden pilaantumista aiheuttaen haasteita kasvisten säilyvyydelle. Hygieniaa ja säilyvyyttä on yritetty parantaa paitsi raakaainevalinnoilla, myös erilaisilla kemiallisilla käsittelyillä ( $\mathrm{mm}$. hapot, vetyperoksidi, otsoni ja elektrolysoitu vesi), fysikaalisilla menetelmillä ( $\mathrm{mm}$. lämpökäsittely, ultraviolettivalo ja korkea paine), pakkausmateriaaleilla ja -kaasuilla sekä varastointiolosuhteilla. Kemiallisilla ja fysikaalisilla hygienisointitekniikoilla pyritään yleensä mikrobimäärien vähentämiseen tai patogeenien eliminoimiseen. Kirjallisuustutkimuksessa selvitettiin kemiallisten ja fysikaalisten hygienisointitekniikoiden vaikutusta pilkottujen tuorekasvistuotteiden mikrobiologiseen laatuun ja säilyvyyteen.

Pilkottujen tuorekasvisten laatua on tutkittu kansainvälisesti erittäin paljon, mutta tutkimuskohteissa on kasviskohtaisia eroja. Esimerkiksi juureksista porkkanaa on tutkittu erittäin paljon, lanttua ja punajuurta vain vähän. Yksittäisen hygienisointikäsittelyn sijaan monet uusimmista tutkimuksista painottuvat yhdistelmätekniikoihin eli erilaisten käsittelymenetelmien yhdistämiseen samanaikaisesti tai peräkkäin.

Useilla hygienisointitekniikoilla on saatu vähennettyä kasvisten normaaliflooraa tai patogeeneja. Valtaosa tutkimuksista osoitti, että useimmat hygienisointikäsittelyt eivät tuhoa kaikkia mikrobeja kasviksesta. Vaikka jollakin hygienisointikäsittelyllä saatiinkin vähennettyä mikrobimääriä hyvinkin pieniksi, mikrobit usein lisääntyivät käsittelyä seuraavalla varastointijaksolla. Kunkin käsittelyn vaikutus kasvistuotteen mikrobiologiseen laatuun vaihteli hyvinkin suuresti eri kasvisten ja niiden pilkontatavan, tutkittujen mikrobien, hygienisoinnin toteutustavan sekä käsittelyolosuhteiden osalta. Minkään katsauksessa esitellyn hygienisointikäsittelyn suhteen ei siis voida esittää yksiselitteistä, yleispätevää vaikutusta kasvisten laatuun.

Mikrobiologisen turvallisuuden ja säilyvyyden lisäksi tärkeitä tuorekasvistuotteen tyypilliset laatuominaisuudet liittyvät ulkonäköön, makuun, ravintoarvoon ja tuntuun. Mikrobiologisen laadun lisäksi hygienisointikäsittelyjen todettiin usein vaikuttavan kasviksen ravitsemukselliseen ja aistinvaraiseen laatuun, joskaan aina näitä vaikutuksia ei todettu tai tutkittu.

Hyvälaatuistenkin tuorekasvisten pinnalla ja sisällä on mikrobeja, ns. normaaliflooraa. Mikrobimäärät yleensä kasvavat kasviksen pilaantuessa ja sen laadun heiketessä. Normaali mikrobifloora saattaa kuitenkin vähentää patogeenien elinmahdollisuuksia. Lisäksi käytännön tuotanto-olosuhteissa kaikkien kasvisten laatuun vaikuttavien tekijöiden seuraaminen ja ylläpitäminen on usein haasteellista. Kussakin tilanteessa tulee arvioida käsittelyjen tavoite, mahdolliset hyödyt ja haitat, tuotantolaitoksen olosuhteet, kustannukset sekä lainsäädäntö. Tulee myös muistaa, että hygienisointimenetelmiä ei tule käyttää korvaamaan hyviä tuotantokäytäntöjä, kuten kylmäketjua ja sen olosuhteita (pääsääntöisesti korkeintaan $+6{ }^{\circ} \mathrm{C}$ ) ja pysyvyyttä, puhtautta ja tuotantohygieniaa sekä nopeaa käsittelyprosessia ja -ketjua.

Kirjallisuustutkimus tehtiin TuoPro (Tuorekasvisten turvallisuuden parantaminen) -hankkeessa, jonka vetäjä oli Luonnonvarakeskus (Luke) ja rahoittajana Hämeen ELY-keskus. Hankkeen tuloksista tiedotetaan vuosina 2015-2016 Maa- ja metsätalousministeriön rahoittamassa TuoPro2 (Hyviä käytäntöjä tuorekasviksia valmistaviin yrityksiin) -hankkeessa, jonka vetäjä on Helsingin yliopiston maataloustieteiden laitos.

Asiasanat: Tuorekasvis, laatu, hygienia, käsittely, tekniikka 


\section{Johdanto}

Pilkottuja tuorekasviksia käytetään yleisesti etenkin suurkeittiöissä. Tuorekasviksen laatutekijät voidaan jaotella kuuluvan ulkonäköön, makuun, ravintoarvoon, tuntuun sekä turvallisuuteen (Francis ym. 2012). Mikrobiologinen laatu on osa turvallisuusominaisuuksia. Hyvälaatuisissakin tuorekasviksissa on mikrobeja ns. normaalifloorana. Mikrobien määrä yleensä kasvaa kasviksen pilaantuessa. Kasvisten solurakenne rikkoutuu pilkottaessa, mikä edistää mikrobien lisääntymistä ja tuotteiden pilaantumista. Normaalifloora saattaa vähentää patogeenien eli tautia aiheuttavien mikrobien elinmahdollisuuksia (Carlin ym. 1996).

Elintarviketeollisuusliiton (ETL 2015) suosituksen mukaan sellaisenaan syötävien tuorekasvisten, muun muassa salaattien ja raasteiden enimmäismikrobimäärät ovat seuraavat: hiivat $1 \times 10^{4}\left(1 \times 10^{5}\right) \mathrm{pmy} / \mathrm{g}$, homeet $1 \times 10^{3}\left(1 \times 10^{4}\right) \mathrm{pmy} / \mathrm{g}$, Bacillus cereus -ryhmä 1 × $10^{2}\left(1 \times 10^{3}\right) \mathrm{pmy} / \mathrm{g}$, koagulaasipositiiviset stafylokokit / S. aureus $1 \times 10^{2}\left(1 \times 10^{3}\right) \mathrm{pmy} / \mathrm{g}$ ja Escherichia coli $1 \times 10^{2}\left(1 \times 10^{3}\right) \mathrm{pmy} / \mathrm{g}$. Ensimmäisenä kerrotun ohjearvon ylittyessä toistuvasti on arvioitava tilanne, suluissa olevan ohjearvon ylittyessä on tehtävä riskinarviointi ja toimijan on ryhdyttävä tarvittaessa toimenpiteisiin (ETL 2015). Raja- tai suositusarvot eivät selvityksemme perusteella ole kansainvälisesti yhteneväiset.

Tässä kirjoituksessa raportoidaan yhteenveto kirjallisuustutkimuksesta (Kuisma ja Kymäläinen 2015), jossa selvitettiin, millaisia kemiallisia ja fysikaalisia käsittelyjä erityisesti pilkottujen tuorekasvistuotteiden mikrobiologisen laadun hallintaan on tutkittu ja millaisia vaikutuksia niillä oli kasvisten mikrobiologiseen sekä mahdollisesti myös aistinvaraiseen ja ravitsemukselliseen laatuun. Katsauksessa selvitettiin porkkanan, lantun, punajuuren, salaatin, tomaatin, kurkun, paprikan, sipulin, purjosipulin ja itujen tutkimuksia.

\section{Tuorekasvisten mikrobiologisen laadun parantamiseen tutkitut menetelmät}

Tuorekasvisten hygieniaa ja säilyvyyttä on yritetty parantaa paitsi lajikevalinnoilla ja hyvillä viljelykäytännöillä, myös kasvisten jatkojalostusvaiheessa raaka-ainevalinnalla, pesemällä, erilaisilla kemiallisilla ja fysikaalisilla käsittelyillä (taulukko 1), mekaanisen prosessoinnin hallinnalla (kuten käyttämällä teräviä leikkuuvälineitä), pakkausmateriaaleilla ja -kaasuilla sekä varastointiolosuhteilla. Näillä keinoilla pyritään vähentämään mikrobimääriä, estämään mikrobien kasvua tai eliminoimaan patogeeneja.

Taulukko 1. Tuorekasviksille tutkittuja dekontaminaatiotekniikoita ja laadun hallintakeinoja (Rico ym. 2007, Kuisma ja Kymäläinen 2015, muokattu).

\begin{tabular}{|c|c|c|}
\hline \multicolumn{2}{|c|}{ Menetelmä } & Esimerkkejä ja tarkennuksia \\
\hline \multirow{8}{*}{ 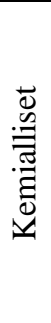 } & Kloori & Hypokloriitti, natriumkloriitti \\
\hline & Klooridioksidi & Vesiliuoksesa tai kaasuna \\
\hline & Orgaaniset hapot & Peretikkahappo, sitruunahappo, maitohappo, viinihappo, askorbiinihappo \\
\hline & Vetyperoksidi & Vesiliuos \\
\hline & Otsoni & Vesiliuoksessa tai kaasuna, kasvisten käsittelyyn pääasiassa vesiliuos \\
\hline & Elektrolysoitu (EO-) vesi & Hapan, emäksinen tai neutraali \\
\hline & "Luonnolliset" säilöntäaineet & Eteeriset öljyt ja syötävät pinnoitteet (sis. kalsiumpohjaiset liuokset) \\
\hline & Muut käsittelyaineet & Bromi, jodi, natriumfosfaatti, kvaternääriset ammoniumsuolayhdisteet \\
\hline \multirow{9}{*}{ 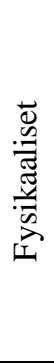 } & Suojakaasupakkaaminen & Eri kaasujen (happi, typpi, hiilidioksidi) seos, tietty pakkauksen läpäisevyys \\
\hline & Lämpökäsittely & Ryöppäys tai lämpöshokki kuuman veden, ilman tai höyryn avulla \\
\hline & Säteilytys & Beeta- tai gammasäteily, sallittu Suomessa vain mausteille \\
\hline & Valokäsittelyt & Ultravioletti(UV)-valo, pulssivalo \\
\hline & Korkea paine & Ilmalla 100-800 MPa, hiilidioksidilla 3-6 MPa \\
\hline & Pulssitettu sähkökenttä & Hyvin harvinainen \\
\hline & Fotokatalyysi & Käytetty UV-käsittelyn yhteydessä \\
\hline & Ultraääni & $25-70 \mathrm{kHz}$ \\
\hline & Fysikaalinen prosessointi & Kuoriminen, leikkaaminen, raastaminen, linkoaminen \\
\hline
\end{tabular}

\footnotetext{
${ }^{1}$ Jos tutkittavan kasviksen viljelyssä on käytetty biopestisidiä (Bacillus thuringiensis), ohjearvo on 1000 pmy/g (10 $000 \mathrm{pmy} / \mathrm{g})(\mathrm{ETL} 2015)$.
} 
Pilkottujen tuorekasvisten laatua käsitteleviä tutkimuksia löytyi erittäin runsaasti, mutta eri kasviksia on tutkittu hyvin eri laajuisesti. Esimerkiksi juureksista porkkanaa on tutkittu erittäin paljon, lanttua ja punajuurta hyvin vähän. Tutkimus on aiemmin painottunut yksittäisiin hygienisointikäsittelyihin, mutta nykyään yhä useammin monia käsittelyjä yhdistetään samanaikaisina tai peräkkäin (Kuisma ja Kymäläinen 2015).

\section{Eri käsittelyjen vaikutukset tuorekasvisten laatuun}

Useimmilla kirjallisuuskatsauksessa (Kuisma ja Kymäläinen 2015) tarkastelluista hygienisointitekniikoista saatiin vähennettyä tuorekasvisten normaalimikrobiflooraa tai patogeenimikrobeja tyypillisesti $1-4,5$ $\log /$ pmy verran. Harvoin saavutettiin yli $5 \log$ vähenemä, mutta esimerkiksi Weissin ja Hammesin (2003) tutkimuksessa lämpökäsittely $55^{\circ} \mathrm{C}$ :ssa 20 min ajan tai $80{ }^{\circ} \mathrm{C}$ :ssa 2 min ajan vähensi mungpapujen Salmonella-määrää yli 5 log itävyyden heikkenemättä.

Yleensä hygienisointikäsittelyt eivät tuhonneet kaikkia mikrobeja kasviksista. Neetoon ym. (2008) tutkimuksessa EHEC (enterohemorraagien E. coli O157:H7) saatiin kuitenkin kokonaan eliminoitua kosteista idätykseen tarkoitetuista sinimailasen siemenistä 15 min kestävällä painekäsittelyllä (600 MPa, $\left.20^{\circ} \mathrm{C}\right)$.

Vaikka mikrobimääriä olisi saatu pienennettyä merkittävästi, mikrobit useimmiten lisääntyivät hygienisointikäsittelyn jälkeen varastoinnissa. Esimerkiksi Rodgersin ym. (2004) tutkimuksessa otsonoidulla vedellä pesu ( $3 \mathrm{mg} / \mathrm{l}, 5 \mathrm{~min})$ vähensi mesofiilisten bakteerien määrää revityssä salaatissa noin 4,0 log pmy/g, mutta bakteerien määrä kasvoi varastoinnin aikana $\left(4{ }^{\circ} \mathrm{C}, 9\right.$ vrk) 2,0-3,0 log pmy/g. RuizCruzin ym. (2007) tutkimuksessa porkkanaraasteessa oli Salmonellaa aluksi 5,84 log pmy/g, peretikkahappokäsittelyn $(40 \mathrm{ppm})$ jälkeen $2,1 \mathrm{log}$ pmy/g vähemmän, mutta varastoinnin $\left(5^{\circ} \mathrm{C}, 10 \mathrm{vrk}\right)$ jälkeen saman verran kuin pelkällä vedellä käsitellyssä raasteessa.

Kunkin hygienisointikäsittelyn vaikutuksessa yhdenkin tuorekasvistuotetyypin (esim. porkkanaraasteen) mikrobiologiseen, aistinvaraiseen ja ravitsemukselliseen laatuun oli usein suuria eroja. Tulosten vaihtelevuuteen vaikuttivat tutkittu kasvistuote ja sen ominaisuudet (mm. lajike ja pilkontatapa), tutkitut mikrobit sekä niiden sijainti ja määrä kasviksen sisällä tai pinnalla, hygienisointikäsittelyn toteutustapa (mm. käsittelytekniikka, konsentraatio tai voimakkuus sekä kestoaika) sekä ympäröivät olosuhteet, kuten lämpötila ja suhteellinen kosteus. Tyypillisesti usean käsittelymenetelmän yhdistäminen tehosti hygienisointivaikutusta verrattuna yksittäisten menetelmien käyttöön. Esimerkiksi Rajkowskin ym. (2007) tutkimuksessa $185 \mathrm{~nm}$ ja $254 \mathrm{~nm}$ yhdistelmä-UVC-käsittely oli hyvin tehokas Shigella sonnei -bakteerin tuhoamisessa agarista (>8 log) ja nesteistä (vesi, kasvisliemi; $>5 \log$ ), mutta itujen pinnan epätasaisuuden vuoksi vähenemä oli niissä vain 2-3 log ja vain, jos käsittelyyn yhdistettiin vetyperoksidikäsittely. Durakin ym. (2012) tutkimuksessa puolestaan UV-valo $\left(125 \mathrm{~mJ} / \mathrm{cm}^{2}\right)$, kloori (Nahypokloriitti $200 \mathrm{ppm})$ ja lämpö $\left(50^{\circ} \mathrm{C}\right)$ yhdessä tuottivat yli $5 \log$ vähenemän vihersipulin pistemäiseen EHEC-pintakontaminaatioon ( $7,2 \mathrm{log} /$ piste $)$, mutta käsittely ei juuri tehonnut sipulin sisäosan kontaminaatioon.

Hygienisointimenetelmiä ei tule käyttää korvaamaan hyviä tuotantokäytäntöjä, kuten kylmäketjua ja sen olosuhteita (pääsääntöisesti korkeintaan $+6{ }^{\circ} \mathrm{C}$ ) sekä olosuhteiden pysyvyyttä, puhtautta ja tuotantohygieniaa, hyvää käsittelytekniikkaa (esim. terävät leikkuuvälineet) sekä nopeaa käsittelyprosessia ja -ketjua. Tuorekasvisalalle valmistui vuonna 2015 Hyvän käytännön ohje (Lehto ym. 2015).

\section{Johtopäätökset}

Erilaisten hygienisointikäsittelyjen vaikutusta tuorekasvisten laatuun on tutkittu kokonaisuutena hyvin paljon, mutta tutkimuksen kohteissa on eri kasvisten ja käsittelyjen osalta eroja. Eri tutkimusten koejärjestelyissä oli merkittäviä, tulosten yleistettävyyteen ja käytännön sovellettavuuteen vaikuttavia eroja. Vaikka monella menetelmällä saatiin vähennettyä kasvisten mikrobimääriä, vaikutukset eivät aina säilyneet varastoinnissa tai kasviksen aistinvarainen ja ravitsemuksellinen laatu kärsi käsittelystä. Tutkimusten vertailtavuus on rajallista koejärjestelyjen eroavuuksien takia. Myös käytännön tuotantoolosuhteissa kaikkien hygienisointikäsittelyn tehoon vaikuttavien tekijöiden seuraaminen ja ylläpitäminen 
on usein haasteellista. Kussakin tilanteessa tulee arvioida käsittelyjen tavoite, mahdolliset hyödyt ja haitat, tuotantolaitoksen olosuhteet, kustannukset sekä lainsäädäntö. Hyviin tuotantotapoihin tulee panostaa kaikissa tilanteissa.

\section{Kiitokset}

Tutkimus tehtiin TuoPro (Tuorekasvisten turvallisuuden parantaminen) -hankkeessa, jonka vetäjä oli Luonnonvarakeskus (Luke) ja rahoittaja Hämeen ELY-keskus. Hankkeen tuloksista tiedotetaan vuosina 2015-2016 Maa- ja metsätalousministeriön rahoittamassa TuoPro2 (Hyviä käytäntöjä tuorekasviksia valmistaviin yrityksiin) -projektissa, jonka vetäjä on Helsingin yliopiston maataloustieteiden laitos ja kanssatoteuttaja Luke. Kiitämme lämpimästi molempien hankkeiden rahoittajia ja yhteistyökumppaneita.

\section{Kirjallisuus}

Carlin, F., Nguyen, C., Abreu da Silva, A. \& Cochet, C. 1996. Effects of carbon dioxide on the fate of Listeria monocytogenes, of aerobic bacteria and on the development of spoilage in minimally processed fresh endive. International Journal of Food Microbiology 32: 159-172.

Durak, M. Z., Churey, J. J. \& Worobo, R. W. 2012. Efficacy of UV, acidified sodium hypo-chlorite, and mild heat for decontamination of surface and infiltrated Escherichia coli O157:H7 on green onions and baby spinach. Journal of Food Protection 75: 1198-1206.

Elintarviketeollisuusliitto ry 2015. Elintarvikkeiden mikrobiologisia ohjausarvoja viimeisenä käyttöpäivänä. Suositus 4.3.2015. Helsinki: $6 \mathrm{~s}$.

Francis, G. A., Gallone, A., Nychas, G. J., Sofos, J. N., Colelli, G., Amodio, M. L. \& Spano, G. 2012. Factors affecting quality and safety of fresh-cut produce. Critical Reviews in Food Science and Nutrition 52: 595-610. Kuisma, R. \& Kymäläinen, H.-R. 2015. Pilkottujen tuorekasvisten hygienia: kirjallisuuskatsaus. Helsingin yliopisto, maataloustieteiden laitoksen julkaisuja 37, Unigrafia: 109 s. Sähköinen julkaisu osoitteessa http://hdl.handle.net/10138/153124.

Lehto, M., Maarit, M., Kuisma, R. \& Kymäläinen, H.-R. 2015. Hyvän käytännön ohje tuorekasviksia pilkkoville yrityksille. Luonnonvara- ja biotalouden tutkimus 10/2015, Luonnonvarakeskus (Luke), verkkojulkaisu osoitteessa http://urn.fi/URN:ISBN:978-952-326-09-2, 129 s.

Neetoo, H., Ye, M. \& Chen, H. Q. 2008. Potential application of high hydrostatic pressure to eliminate Escherichia coli O157:H7 on alfalfa sprouted seeds. International Journal of Food Microbiology 128: 348-353.

Rajkowski, K.T. 2007. Inhibition of Shigella sonnei by ultraviolet energy on agar, liquid media and radish sprouts. Journal of Food Safety 27: 233-240.

Rico, D., Martin-Diana, A. B., Barat, J. M. \& Barry-Ryan, C. 2007. Extending and measuring the quality of fresh-cut fruit and vegetables: a review. Trends in Food Science \& Technology 18: 373-386.

Rodgers, S. L., Cash, J. N., Siddiq, M. \& Ryser, E. T. 2004. A comparison of different chemical sanitizers for inactivating Escherichia coli O157:H7 and Listeria monocytogenes in solution and on apples, lettuce, strawberries, and cantaloupe. Journal of Food Protection 67: 721-731.

Weiss, A. \& Hammes, W. P. 2003. Thermal seed treatment to improve the food safety status of sprouts. Journal of Applied Botany-Angewandte Botanik 77: 152-155. 